stroke, preventive strategies that include lowering blood cholesterol should not be tempered because of concerns about a possible increased risk of haemorrhagic stroke.

Contributors: See bmj.com.

Funding: Ministry of Health and Welfare Korea (01-PJ1-PG101CH10-0007) and MH63749 from the National Institutes of Mental Health. DAL is funded by a UK Department of Health career scientist award.

Competing interests: None declared.

Ethical approval: Internal review board of Samsung Medical Centre and Korea National Health Insurance Corporation.

1 Ariesen MJ, Claus SP, Rinkel GJ, Algra A. Risk factors for intracerebral haemorrhage in the general population. A systematic review. Stroke 2003;34:2060-6.

2 Prospective Studies Collaboration. Cholesterol, diastolic blood pressure, and stroke: 13,000 strokes in 450,000 people in 45 prospective cohorts. Lancet 1995;346:1647-53.

3 Hart CL, Hole DJ, Davey Smith G. Risk factors and 20-year stroke mortality in men and women in the Renfrew/Paisley study in Scotland. Stroke 1999;30:1999-2007.
4 Iso H, Jacobs DR Jr, Wentworth D, Neaton JD, Cohen JD for the Multiple Risk Factor Intervention Trial Research Group. Serum cholesterol levels Risk Factor In and six-year mortality from stroke in 350,977 men screened for the multiple risk factor intervention trial. N Engl J Med 1989;320:904-10.

5 Corvol JC, Bouzamondo A, Sirol M, Hulot JS, Sanchez P, Lechat P. Differential effects of lipid-lowering therapies on stroke prevention: a meta-analysis of randomized trials. Arch Int Med 2003;163:669-76.

6 Cholesterol Treatment Trialists' (CTT) Collaborators. Baigent C, Keech A, Kearney PM, Blackwell L, Buck G, Pollicino C, et al. Efficacy and safety of cholesterol-lowering treatment: prospective meta-analysis of data from 90,056 participants in 14 randomised trials of statins. Lancet 2005:366:1267-78

7 Chen Z, Keech A, Collins R, Slavin B, Chen J, Campbell TC, et al. Prolonged infection with hepatitis $\mathrm{B}$ and association between low blood Prolonged infection with hepatitis B and association between low
cholesterol concentration and liver cancer. BMJ 1993;306:890-4.

8 Reynolds K, Lewis LB, Nolen JD, Kinney GL, Sathya B, He J. Alcohol consumption and risk of stroke: a meta-analysis. JAMA 2003;289:579-88. 9 Iribarren C, Reed DM, Burchfiel CM, Dwyer JH. Serum total cholesterol and mortality: confounding factors and risk modification in JapaneseAmerican men. JAMA 1995;273:1926-32.

10 Hart CL, Davey Smith G, Hole DJ, Hawthorne VM. Alcohol consumption and mortality from all causes, coronary heart disease and stroke: results from a prospective cohort of Scottish men with 21 years of follow up. BMJ 1999;318:1725-9.

(Accepted 14 April 2006)

doi $10.1136 /$ bmj.38855.610324.80

\title{
Smoking, obesity, and their co-occurrence in the United States: cross sectional analysis
}

\author{
Cheryl G Healton, Donna Vallone, Kristen L McCausland, Haijun Xiao, Molly P Green
}

\begin{abstract}
Objectives To describe the prevalence of obesity, smoking, and both health risk factors together among adults in the United States.

Design Cross sectional analysis of a national health interview survey.

Setting United States.

Participants 29305 adults (aged $\geq 18$ ) in 2002.

Main outcome measures Prevalence of adults who are obese (body mass index $\geq 30$ ), who smoke, and who are obese and smoke. Prevalence was stratified by age, sex, ethnic group, education, and income.

Results $23.5 \%$ of adults were obese, $22.7 \%$ smoked, and $4.7 \%$ smoked and were obese.

Conclusions Although the proportion of adults who smoke and are obese is relatively low, this subgroup is concentrated among lower socioeconomic groups.
\end{abstract}

\section{Introduction}

Obesity and cigarette smoking are primary risk factors for several chronic conditions and early death in a large number of people in the United States. The prevalence of smoking among adults is 22.5\% (45.8 million people). ${ }^{1}$ The proportion of obese adults is also high-about $31 \%$ of adults have a body mass index of 30 or more. ${ }^{2}$ Although smoking and obesity are public health priorities in the US, ${ }^{3}$ the overlap between the two conditions has not been measured at population level. Because the presence of these two conditions together probably carries an increased risk to health, statistics on how these conditions overlap could help in the development of an effective policy for prevention and treatment.

\section{Methods}

We used data from the 2002 national health interview survey (NHIS) to conduct a cross sectional analysis of 29305 adults ( $\geq 18$ years) and estimate the proportion of adults in the US who smoke and are obese. Prevalence was stratified by various sociodemographic factors. Rubin's multiple imputation procedure was used to replace missing values of family income. We analysed all data with Stata software, version 8 and adjusted the results with sampling weights to derive population estimates from the survey sample.

\section{Results}

Nearly $41.5 \%$ of adults (81 million aged $\geq 18$ years) in the US are obese or smoke, and about $4.7 \%$ (9 million) smoke and are obese (table). Overall, $5.3 \%$ of men and $4.2 \%$ of women smoke and are obese. This proportion is higher in African Americans (7.0\%) than in other racial or ethnic groups. A greater proportion of people with lower income and education levels smoke and are obese. With the exception of the over 65 age group, in which the prevalence of both conditions is low $(1.1 \%$; probably because these risk factors are associated with early death), little variation occurs across age groups.

\section{Discussion}

Although the proportion of adults who smoke and are obese in the US is relatively low (4.7\%), the total number is 9 million. Each condition carries an independent health risk, and the presence of both

This article was posted on bmj.com on 12 May 2006: http://bmj.com/cgi/ doi/10.1136/bmj.38840.608704.80
Columbia

University, Mailman School of Public Health, New York, NY, USA

Cheryl G Healton professor of clinical public health

American Legacy Foundation, Washington, DC 20036, USA

Donna Vallone associate vice president of research and evaluation

Kristen L

McCausland

research associate

Haijun Xiao

research analyst

Molly P Green research associate

Correspondence to: C G Healton

chealton@ americanlegacy.org

BMJ 2006;333:25-6 
Prevalence of obesity, smoking, and both risk factors among adults ( $\geq 18$ years): US National Health Interview Survey, 2002. Values are percentages ( $95 \%$ confidence intervals)

\begin{tabular}{|c|c|c|c|c|c|}
\hline \multirow[b]{2}{*}{ Characteristics } & \multicolumn{2}{|c|}{ Sample size } & \multirow{2}{*}{$\begin{array}{c}\text { Obese }^{*} \\
\text { (weighted } n=45398794 \text { ) }\end{array}$} & \multirow{2}{*}{$\begin{array}{c}\text { Smokert } \\
\text { (weighted } n=43710 \text { 065) }\end{array}$} & \multirow{2}{*}{$\begin{array}{c}\text { Obese and smoker } \\
\text { (weighted } n=9087 \text { 068) }\end{array}$} \\
\hline & Actual & Weighted & & & \\
\hline \multicolumn{6}{|l|}{ Age (years): } \\
\hline $18-24$ & 3176 & 25998063 & 14.9 (13.4 to 16.5$)$ & 28.8 (26.8 to 30.9$)$ & 4.5 (3.7 to 5.6$)$ \\
\hline $25-34$ & 5520 & 34991228 & 22.2 (20.9 to 23.5 ) & 24.8 (23.5 to 26.2$)$ & 5.7 (5.0 to 6.5$)$ \\
\hline $35-44$ & 6130 & 41605141 & 25.0 (23.7 to 26.3 ) & 26.9 (25.6 to 28.4$)$ & 6.1 (5.5 to 6.9$)$ \\
\hline $45-54$ & 5161 & 36827949 & 27.1 (25.7 to 28.6 ) & 25.0 (23.7 to 26.4$)$ & 6.0 (5.2 to 6.8$)$ \\
\hline $55-64$ & 3752 & 24214894 & 28.7 (27.1 to 30.4 ) & 20.0 (18.7 to 21.4) & 4.0 (3.4 to 4.7$)$ \\
\hline$\geq 65$ & 5566 & 31542770 & 22.1 (20.9 to 23.4 ) & $9.2(8.4$ to 10.1$)$ & 1.1 (0.9 to 1.5$)$ \\
\hline \multicolumn{6}{|l|}{ Sex: } \\
\hline Male & 12989 & 95502862 & 24.1 (23.2 to 25.0 & 25.3 (24.5 to 26.3 ) & 5.3 (4.8 to 5.8$)$ \\
\hline Female & 16316 & 99677183 & 23.0 (22.2 to 23.8$)$ & 20.2 (19.4 to 21.1) & 4.2 (3.9 to 4.6$)$ \\
\hline \multicolumn{6}{|l|}{ Ethnic origin: } \\
\hline White & 19493 & 143822860 & 22.2 (21.5 to 22.9$)$ & 23.8 (23.0 to 24.6$)$ & 4.6 (4.2 to 5.0$)$ \\
\hline Black & 3965 & 22269346 & 35.1 (33.3 to 37.0$)$ & 23.1 (21.4 to 24.8$)$ & 7.0 (6.1 to 8.1$)$ \\
\hline Hispanic & 4785 & 20590479 & 25.2 (23.7 to 26.8 ) & 17.1 (15.9 to 18.4$)$ & 4.2 (3.6 to 5.0$)$ \\
\hline Other & 1062 & 8497360 & 11.8 (9.3 to 14.7$)$ & 17.9 (15.5 to 20.6) & 3.0 (1.9 to 4.7$)$ \\
\hline \multicolumn{6}{|l|}{ Education: } \\
\hline Did not finish high school & 5498 & 31611890 & 27.5 (26.1 to 29.0$)$ & 29.6 (28.3 to 31.0$)$ & 6.1 (5.3 to 6.9$)$ \\
\hline High school graduate or equivalent & 8412 & 57704002 & 26.0 (24.8 to 27.2$)$ & 28.6 (41.5 to 49.0$)$ & 6.1 (5.5 to 6.8$)$ \\
\hline AA $\neq$ degree or college but no degree & 8374 & 56576273 & 24.1 (22.9 to 25.3) & 22.9 (21.7 to 24.1$)$ & 5.0 (4.4 to 5.7$)$ \\
\hline Bachelor degree & 6808 & 47900038 & 17.4 (16.4 to 18.4$)$ & 10.8 (10.0 to 11.6$)$ & 1.8 (1.5 to 2.3$)$ \\
\hline \multicolumn{6}{|l|}{ Annual family income: } \\
\hline$<\$ 20000$ & 7303 & 35271941 & 25.8 (24.6 to 27.1$)$ & 29.8 (28.4 to 31.2 ) & 6.5 (5.8 to 7.3$)$ \\
\hline$\geq \$ 20000$ & 20288 & 148527413 & 23.1 (22.3 to 23.8$)$ & 21.3 (20.6 to 22.0$)$ & 4.5 (4.1 to 4.9$)$ \\
\hline Overall & 29305 & 195180045 & 23.5 (22.9 to 24.2 ) & 22.7 (22.1 to 23.4$)$ & 4.7 (4.4 to 5.1$)$ \\
\hline
\end{tabular}

*Body mass index of $\geq 30.0$.

† Has smoked $>100$ cigarettes and smokes either every day or some days.

$\ddagger$ Associate of Arts degree: two year course that covers the first two years of a four year bachelor degree.

conditions may have increased risks, but little is known about the best treatment for people who smoke and are obese. ${ }^{45}$ Average weight gains of 2.8 to $4.4 \mathrm{~kg}$ for men and 3.8 to $5.0 \mathrm{~kg}$ for women occur when people stop smoking, ${ }^{6}$ but a high proportion of people who stop smoking have large and persistent weight gain. The benefits of stopping smoking are thought to outweigh the risk of weight gain in the overall population, ${ }^{6}$ but the effects on people who are obese are unclear. It is not known whether people who smoke and are obese are less, more, or equally likely to gain weight than people who are not obese. Conversely, it is not known how restricting dietary intake affects attempts to stop smoking and relapse among obese people. Currently, most programmes for stopping smoking do not encourage simultaneous attempts at weight control because interventions aimed at changing several health behaviours have not been very successful. ${ }^{8}$

\section{What is already known on this topic}

Smoking and obesity are two of the leading causes of mortality and morbidity in the United States

Lower socioeconomic groups are disproportionately affected by smoking and obesity

\section{What this study adds}

The overlap of smoking and obesity among adults in the US is low (4.7\%), but the total number of people affected is 9 million, and this subgroup is concentrated among lower socioeconomic groups

Statistics on the overlap of these two conditions could help inform clinical interventions
Treatments for people who smoke and who are obese need to be investigated. Clinical trials should monitor the effects of programmes aimed at simultaneously stopping smoking and weight control to document and respond to any unintended consequences. These results could be used to develop protocols for the optimal clinical management of this population.

Contributors: CGH conceived and designed the study and helped prepare the final draft. DV directed the data analysis and helped prepare the final draft. KLM helped interpret the data and prepared the original draft manuscript. MPG helped interpret the data and prepare the final draft. HX conducted the analyses and helped prepare the original draft manuscript.

Funding: American Legacy Foundation.

Competing interests: None declared.

1 Centers for Disease Control and Prevention (CDC). Cigarette smoking among adults-United States, 2002. MMWR Morb Mortal Wkly Rep 2004;53:427-31.

2 Hedley AA, Ogden CL, Johnson CL, Carroll MD, Curtin LR, Flegal KM. Prevalence of overweight and obesity among US children, adolescents, and adults, 1999-2002. JAMA 2004;291:2847-50.

3 Healthy People 2010. 2nd ed. Washington, DC: US Department of Health and Human Services, 2000. www.healthypeople.gov/document $/ \mathrm{html}$ tracking/THP_Intro.htm (accessed 3 May 2006).

4 Greenlund KJ, Zheng ZJ, Keenan N, Giles WH, Casper ML, Mensah GA, et al. Trends in self-reported multiple cardiovascular disease risk factors among adults in the United States, 1991-1999. Arch Intern Med 2004; 164:181-8.

5 Marrero JA, Fontana RJ, Fu S, Conjeevaram HS, Su GL, Lok AS. Alcohol, tobacco, and obesity are synergistic risk factors for hepatocellular cabcinoma. J Hepatol 2005;42:218-24.

6 Flegal KM, Troiano R, Ramuk E, Kuczmarski RJ, Campell SM. The influence of smoking cessation on the prevalence of overweight in the United ence of smoking cessation on the prevale
States. N Engl J Med 1995:333:1165-70.

7 Williamson DF, Madans J, Anda RF, Kleinman JC, Giovino GA, Byers T. Smoking cessation and severity of weight gain in a national cohort. $N$ Engl J Med 1991;324:739-45.

8 Copeland AL, Martin PD, Geiselman PJ, Rash CJ, Kendzor DE. Smoking cessation for weight-concerned women: group vs. individually tailored, dietary, and weight-control follow-up sessions. Addict Behav 2006;31:115-27. (Accepted 29 March 2006)

doi $10.1136 /$ bmj. 38840.608704 .80 